\title{
EKOSENTRISME MENGAWAL KEARIFAN ARSITEKTUR INDONESIA MENUJU PERADABAN MASA DEPAN: DISKURSUS
}

\author{
${ }^{1}$ Ismail, ${ }^{2}$ Rita Laksmitasari Rahayu \\ ${ }^{1}$ Universitas Indraprasta PGRI, Program Studi Arsitektur \\ zubdahismail76@gmail.com \\ ${ }^{2}$ Universitas Indraprasta PGRI, Program Studi Arsitektur \\ ritalaxmi@gmail.com
}

\begin{abstract}
Development in the built environment involves architects as planners. One of the architect's works is a high-rise building. High-rise buildings in Indonesia affect the social and cultural aspects of the community. Architectural works are present without forgetting environmental ethics. Anthropocentrism moves into ecosentrism which makes people aware that they cannot be separated from nature. The presence of buildings in the universe (macro cosmos) is the scope of modern science and the latest technology. The scientific method, with all its imperfections, can be used to improve social, political, and economic systems, and it continues to apply, whatever the improvement criteria that are applied. Indonesian architects must move toward ecocentric thinking with a localized value. Need awareness to cultivate modern science that can help humans. Processing modern science also maintains the universe for human interests in social, cultural values in addition to economic, technological and political values.
\end{abstract}

Key Words: anthropocentrism, ecocentrism, macro cosmos, science, technology

\begin{abstract}
Abstrak : Pembangunan pada lingkungan binaan melibatkan arsitek sebagai perencana. Salah satu karya arsitek yaitu bangunan bertingkat tinggi. Bangunan bertingkat tinggi di Indonesia mempengaruhi aspek sosial dan budaya masyarakatnya. Karya arsitektur hadir tanpa melupakan etika lingkungan. Antroposentrisme bergerak menjadi ekosentrisme yang menyadarkan manusia tidak bisa lepas dari alam. Kehadiran bangunan pada alam semesta (makro kosmos) merupakan lingkup sains modern dan teknologi terkini. Metode sains, dengan segala ketidaksempurnaannya, dapat digunakan untuk memperbaiki sistem sosial, politik, dan ekonomi, dan itu terus berlaku, apa pun kriteria perbaikan yang diterapkan. Para arsitek Indonesia harus bergerak ke arah pemikiran ekosentris dengan nilai kelokalan. Perlu kesadaran untuk mengolah sains modern yang dapat membantu manusia. Mengolah sain modern juga tetap menjaga alam semesta untuk kepentingan manusia pada nilai sosial, budaya selain nilai ekonomi, teknologi, dan politik.
\end{abstract}

Kata Kunci : antroposentrisme, ekosentrisme, makro kosmos, sains, teknologi

\section{PENDAHULUAN}

Indonesia memiliki cerita panjang sejarah arsitekturnya, mulai dari arsitektur tradisional sampai masa modern arsitektur Indonesia. Arsitektur Indonesia kaya baik secara filosofi, bentuk, dan nilai estetis. Arsitektur Indonesia memiliki banyak bangunan organik seperti rumah bali, rumah gadang, ruma bolon, rumah bugis, rumah nias, tongkonan toraja, rumah asmat, dan lainnya. Sejarah arsitektur Indonesia terbagi menjadi 3 periode, yaitu arsitektur candi, arsitektur tradisional, dan arsitektur kolonial (Myrtha;11).

Pada periode arsitektur tradisional, masyarakat begitu sadar untuk "bekerja sama" dengan alam, dimana alam tidak lepas dari satu desain arsitektur Indonesia.
Setelah periode arsitektur tradisional, perkembangan arsitektur Indonesia dipengaruhi oleh kebudayaan barat. Ilmu pengetahuan dan teknologi baru mempengaruhi bentuk bangunan di Indonesia masa itu dan keterlibatan alam sudah mulai luntur. Paradigma Cartesian-Newtonian mendominasi setiap desain dan arsitektur Indonesia.

Indonesia harus memiliki kesiapan dalam menghadapi gelombang peradaban dunia. Peradaban dunia bukan tiba tiba hadir di Indonesia tapi peradaban dunia terus selalu mempengaruhi peradaban di Indonesia mulai dari Indonesia berinteraksi dengan peradaban dunia.

Seluruh bangunan yang terbangun di alam ini, memberikan konsekuensi terhadap alam. Konsekuensi ini yang belum dipikirkan oleh para 
desainer (infrastruktur, bangunan, dan lainnya). Para arsitek lebih condong pada paradigma Cartesian-Newtonian. Hal ini imbas dari perkembangan ilmu pengetahuan dan teknologi dunia.

Perkembangan dan kemajuan aspek sosial, ekonomi, politik, teknologi, dan budaya masyarakat Indonesia mempengaruhi bangunan modern banyak dibangun Banyak bermunculan bangunan-bangunan yang memiliki disain spektakuler diantaranya bangunan bertingkat baik bertingkat rendah, sedang, dan tinggi.

Salah satu perkembangan peradaban di Indonesia ditandai dengan banyak dibangun bangunan bertingkat tinggi. Faktor teknologi mengiringi pembangunan bangunan bertingkat tinggi. Bangunan bertingkat tinggi bukan lagi keinginan tapi suatu kebutuhan.

\section{OBYEK dan PERSOALAN}

Berbagai bentuk, ukuran, dan tampilan bangunan bertingkat tinggi secara tidak langsung mempengaruhi politik dan ekonomi suatu negara. Bentuk spektakuler bangunan bertingkat tinggi menggunakan teknologi mega structure. Nilai prestis dan nilai ekonomi bagi negara yang memiliki bangunan bertingkat super tinggi spektakuler. Beberapa value dari nilai wisata atau nilai jual wisata akan menghasilkan devisa bagi negara yang bersangkutan. Tuntuntan tersebut memancing para arsitek berlomba terus menerus menciptakan bangunan yang berbeda. Gegap gempita pembangunan mega structure melahirkan fenomena pembangunan yang meledak lebih pada eksplorasi dan eksplotasi ide serta kreativitas arsitek. Arsitek berlomba terlihat eksis sehingga hanya mengedepankan ego semata. Memuja krativitas manusia/arsitek, teknologi bisa mengakomodir ide ide fantatis, apakah arsitek akan atau sudah melupakan etika lingkungan?

\section{PEMBAHASAN}

\section{Peradaban}

Peradaban manusia terus berjalan sesuai dengan bergeraknya semua elemen yang mempengaruhinya. Elemen-elemen peradaban berada pada struktur sosial, budaya, politik, ekonomi, dan teknologi yang sedang dijalankan oleh manusia. Arah peradaban sangat tergantung dari visi atau konsep yang sedang dimainkan. Bila dikaitkan dengan ilmu pengetahuan, tidak ada pemisahan yang tegas antara metode dan obyek ilmu, antara subyek dan obyek. Ketika subyek itu mengamati obyek, obyek tersebut telah ditangkap dalam perspektif si subyek. Maka tidak ada namanya obyek pada diri sendiri. Obyek sudah ditingkat dalam subyektivitas subyek. Sebaliknya, tidak ada obyek yang murni begitu saja, karena setiap obyek yang diamati dan diteliti sudah ditafsirkan dalam kerangka subyektivitas (kemampuan ilmiah, persepsi, asumsi) subyek (Keraf; 341)

Kalau boleh saya katakan, peradaban adalah sebuah panggung besar dimana manusia secara bersama sama selain menjadi sutradara sekaligus menjadi lakonnya yang memainkan karakter dalam hal ini karakter tersebut adalah elemen-elemen peradaban (sosial, budaya, politik, ekonomi, dan teknologi). Kekuatan "cerita" peradaban terletak dari hasil mega skenario yang menghasilkan energi maha dahsyat sehingga memberikan karakter kuat dari suatu peradaban pada masanya. Pada peradaban masa lalu, perumpamaan panggung besar tersebut tanpa penonton. Ada yang terlupa...... "penonton". Manusia asyik sendiri dengan mega skenario yang dijalankan. Manusia lupa bahwa sebuah mega skenario membutuhkan respon dari pihak lain, respon tersebut adalah "penonton". Manusia lupa bahwa peradaban bisa memberikan respon. Manusia lupa bahwa ada pihak lain yang bisa merespon hasil mega skenario tersebut. Pada saat itu, manusia menganut paham antroposentris, manusia adalah pusat dari segalanya. Pandangan lain, tanpa manusia, apakah alam memiliki nilai independen? Masih pada aliran antroposentris, alam hanya berharga dalam konteks kegunaannya terhadap kesejehteraan manusia (Saras Dewi; 3). Atau pada konteks ini, "penonton" mendapatkan nilai pada saat mega skenario tersebut berhasil dibawakan dengan baik.

Manusia sebagai penonton memberikan respon "emosi" dari mega skenario tersebut. Manusia bukan hanya sebagai subyek yang dapat 
mengatur "panggung" sehingga sesuai kepentingan manusia semata, tetapi manusia juga merespon ke-subyek-an tersebut sehingga hasil mega skenario tersebut mendapat respon dari penikmat skenario. Perlu digarisbawahi bahwa subyek bukan hanya manusia sebagai lakon saja tetapi juga manusia sebagai penonton. Manusia sebagai sutradara, manusia sebagai lakon, dan manusia sebagai penonton saling berkomunikasi sehingga terdapat keberhasilan skenario. Tidak ada pengamat independen, yang ada hanya peserta dalam realitas. Yang ada sesungguhnya adalah subyek yang terlibat dalam realitas obyek yang diteliti (Sonny Keraf; 341).

Begitu pula dengan peradaban, komunikasi yang baik antara manusia dengan alam yang seimbang akan menghasilkan peradaban masa depan yang baik. Hal ini terkadang membuat kekhawatiran beberapa orang akan peradaban masa depan. Berkembangnya peradaban yang demikian cepat dengan didukung oleh teknologi yang sangat maju, seakan peradaban berkembang diluar kendali. Beberapa orang sadar dan mencari cara bagaimana mengekang peradaban menjadi lebih baik dan tidak berkembang "liar" sehingga seakan akan manusia tidak dikendalikan oleh teknologi. Fritjof Capra dalam Sonny Keraf mengatakan pola-pola yang diamati para ilmuwan dalam alam terkait erat dengan pola-pola yang ada dalam pikiran mereka; dengan konsep, pemikiran, dan nilai yang mereka miliki. Sebelum lebih jauh, kita akan kembali dulu pada peradaban.

Sebelumnya, saya mengumpamakan peradaban adalah hasil dari mega skenario yang menghasilkan energi yang maha dahsyat. Salah satu genre yang dimainkan oleh manusia adalah budaya, selain sosial, politik, dan ekonomi. Peradaban terus bergerak, terus, terus, dan terus, seluruh energi digunakan untuk bergerak seperti bola salju, terus mencari titik akhir yang dianggap sempurna. Setelah energi dieksploitasi seoptimal mungkin, bisa dikatakan energi akan mencapai titik maksimum (puncak vitalitas), maka peradaban cenderung kehilangan tenaga budayanya dan kemudian runtuh (Capra;12). Menurut Toynbee dalam buku Capra, suatu elemen penting dalam keruntuhan budaya akibat dari hilangnya fleksibilitas. Pada waktu struktur sosial dan pola perilaku telah menjadi kaku sehingga masyarakat tidak lagi mampu menyesuaikan diri dengan situasi yang berubah, peradaban itu tidak akan mampu menyesuaikan diri dengan situasi yang berubah, peradaban itu tidak akan mempu melanjutkan proses kreatif evolusi budayanya dia akan hancur akan secara berangsur mengalami disintegrasi.

Apa yang terjadi dengan perkembangan peradaban masa kini? Perlu diketahui bahwa ada kearifan sistemik yang merupakan ciri khas kebudayaan-kebudayaan tradisional non tulis yang saat ini telah diabaikan. Perkembangan peradaban membawa masyarakat terlalu rasional dan termekanisasi. Kearifan sistemik didasarkan atas suatu penghormatan yang tinggi pada kearifan alam yang sepenuhnya konsisten dengan wawasan-wawasan ekologi modern. Hal yang penting dan kadang manusia lupa tentang lingkungan alam. Lingkungan alam terdiri atas ekosistem-ekosistem yang dihuni oleh organismeorganisme yang tak terhitung yang telah berevolusi bersama selama miliaran tahun, yang secara terus menerus menggunakan dan mendaur ulang molekul molekul tanah, air, dan udara yang sama. Prinsip-prinsip pengatur ekosistemekosistem ini harus dianggap lebih unggul daripada prinsip prinsip teknologi manusia yang didasarkan pada penemuan-penemuan baru baru ini dan seringkali pada proyeksi poyeksi linier jangka pendek (Capra;486).

Melihat arsitektur tradisional Indonesia sangat memperhatikan unsur alam, yang merupakan bagian dari kebijakan dan kearifan pembangunan ruang hidup masyarakatnya. Terdapat keserasian dan keselarasan antara makro kosmos (alam semesta) dan mikro kosmos (bangunan) yang harus selalu diperlihara (Myrtha; 24). Kekuatan hubungan manusia dan alam seharusnya mengawal perkembangan peradaban global. Menyikapi prinsip prinsip tersebut maka diperlukan hubungan timbal balik yang dinamis antara kecenderungankecenderungan yang saling melengkapi. Kesinambungan global persoalan-persoalan kita dan kebajikan dari perusahan perusahaan skala kecil yang didesentralisasikan merupakan 
sepasang perlawanan yang saling melengkapi. Untuk itu perlu keseimbanganan antara keduanya telah terungkap pada slogan "berpikirlah secara global, berbuatlah secara lokal" (Capra;487).

Perkembangan peradaban erat dengan pertumbuhan kota yang merupakan salah satu ancaman terbesar bagi keseimbangan sosial dan ekologis, oleh karena itu deurbanisasi akan menjadi suatu aspek yang menentukan bagi pengembalian ke skala yang lebih manusiawi. Proses deurbanisasi bukan merupakan sesuatu yang perlu digagalkan, proses tersebut hanya perlu dimungkinkan untuk terjadi. Yang diperlukan untuk mengekang pertumbuhan kota adalah menciptakan insentif ekonomi, teknologi, dan program-program tepat bantuan yang akan dimungkinkan orang-orang melakukan transisi dan kehidupan kota ke kehidupan pedesaan. Schumacher pada buku Fritjof Capra mengatakan "kearifan menuntut suatu orientasi ilmu dan teknologi baru yang bersifat organik, lembut, halus, anggun, dan cantik" realitas baru ini merupakan suatu pemberian arah kembali pada teknologi semacam itu menawarkan keempatan yang luar biasa lagi kreativitas, kewiraswastaan dan inisiatif manusia. Visi realitas baru ini merupakan suatu visi ekologis dalam pengertian visi yang melampaui kepedulian-kepedulian langsung pada perlindungan lingkungan.

\section{Antroposentrisme}

Dalam perkembangan peradaban mengenal aliran pemikiran antroposentrisme. Teori etika lingkungan hidup memandang manusia sebagai pusat dari sistem alam semesta. Pemahaman ini mendudukan manusia dan kepentingannya terletak pada posisi paling menentukan baik dalam tatanan ekosistem dan juga kebijakan yang diambil dalam kaitannya dengan alam, baik secara langsung maupun tidak langsung (Sonny Keraf;47). Aliran pemikiran ini digunakan dalam waktu lama dan dirasakan bersifat egois. Kepentingan manusia sebagai hal yang utama tanpa memperhatikan kepentingan makhluk hidup lain dan makro kosmos (alam semesta) seluruhnya.

Aliran pemikiran antroposentrisme termasuk dalam paradigma cartesian-newtonian.
Pada abad ke-18 dan ke-19 Teori Newton mampu menjelaskan gerak planet, bulan, dan komet secara detail. Paradigma Cartesian-Newtonian sudah digunakan kurang lebih tiga ratus tahun lamanya dan cara berpikir manusia dalam mengeksplotasi alam. Keberadaan alam semesta (makro kosmos) untuk mendukung revolusi industri.

Hanya nilai ekonomi semata mendasari kepentingan manusia. Instrumentalistik, hubungan antara manusia dan lingkungan dilihat hanya dalam hubungan instrumental yaitu alam dianggap hanya sebagai alat untuk kepentingan manusia. Pemikiran ini dinilai sangat sempit dalam memandang makro kosmos, sehingga dinamakan shallow environmental ethics. Manusia mengeksploitasi alam secara besarbesaran tanpa memperhatikan kemampuan dan kondisi makro kosmos secara keseluruhan. Sikap atau perilaku rakus dan tamak muncul yang menyebabkan krisis lingkungan hidup.

Berbicara sains juga berbicara teknologi, dimana sains dan teknologi merupakan dua hal yang tidak dapat dipisahkan. Perkembangan keduanya saling mempengaruhi dan tidak dapat lepas dari kehidupan manusia. Pegaruh sains dan teknologi pada kehidupan manusia dapat memberikan hasil yang positif tetapi juga dapat menimbulkan dampak negatif. Sains dan teknologi yang tidak dilaksanakan dengan bijak dan tidak ada pemahaman yang benar dan tepat maka kolaborasi tersebut dapat mendatangkan bencana, cepat atau lambat kejahilan dan kekuasaan akan "meledak" (Carl Sagan; 30). Kata-kata yang seharusnya membuat sains tidak arogan adalah sains sama sekali bukan alat pengetahuan yang sempurna, tetapi hanyalah sesuatu yang terbaik yang dimiliki manusia. Sains bisa diterima dalam kehidupan manusia karena cara berpikir saintifik yang bersifat imajinatif sekaligus disiplin.

\section{Ekosentrisme}

Setelah dipandang aliran pemikiran antroposentris sangat merugikan makro kosmos, lahirlah aliran pemikiran biosentrisme. Aliran pemikiran ini menyatakan tidak benar bahwa hanya manusia yang mempunyai nilai. Alam juga 
mempunyai nilai pada dirinya sendiri lepas dari kepentingan manusia (Sonny Keraf;65). Konsekuensinya makro kosmos (alam semesta) merupakan komunitas moral dimana setiap kehidupan dalam alam semesta ini (manusia, bukan manusia, atau mahkluk lain) memiliki nilai moral yang sama.

Aliran biosentrisme bergerak pada komunitas biotis saja. Pada aliran pemikiran ini, komunitas ekologis adalah seluruh makhluk hidup dan semua benda-benda abiotis saling terkait satu sama lain. Jelas kewajiban dan tanggung jawab moral tidak hanya dibatasi pada makhluk hidup, tetapi juga berlaku terhadap semua realitas ekologis. Salah satu teori ekosentrisme adalah toeri ekologi-dalam dari Arne Næes. Arne Rudolf Ludvig Raab atau dikenal dengan Arne Næss warga negara Norwegia yang lahir di Norwegia pada 8 Desember tahun 1937.

Ekologi-Dalam adalah aliran pemikiran yang dicetuskan oleh Arne Næes dalam gerakan yang menolak pandangan alam hanya relevan karena kepentingan manusia saja. Alam bagian dari kehidupan manusia karena manusia termasuk dalam makro kosmos (alam semesta) dan ada masa depan manusia di dalam kelangsungan alam yang berkelanjutan. Lebih jelasnya EkologiDalam memberikan pemahaman baru tentang hubungan yang era tantara manusia dengan alam secara etis. Alam adalah kesatuan cybernetic, yaitu memiliki sistem keseimbangan yang swa kendali (self-regulating), dimana alam memiliki keseimbangan yang sangat penting bagi kelangsungan setiap spesies yang bergantung padanya.

Kemunculan aliran pemikiran ini menjadi sangat penting selama peradaban manusia, karena berubahnya aliran pemikiran dari suatu etika yang menempatkan manusia sebagai pusat dari alam (antroposentrisme) menjadi aliran pemikiran dari suatu etika yang menempatkan makhluk hidup dan lingkungan menjadi satu kesatuan (ekosentrisme). Tidak lagi ada wujud diskriminasi yang dilakukan manusia tetapi terdapat 9 prinsip dalam beretika dengan lingkungan, yaitu sikap hormat kepada alam (respect for nature), tanggung jawab (moral responsibility for nature), soliaritas kosmis (cosmic solidarity), kasih sayang dan kepedulian terhadap alam (caring for nature), tidak merugikan (no harm), hidup sederhana dan selaras dengan alam, keadilan, demokrasi, dan moral (Sonny Keraf;166)

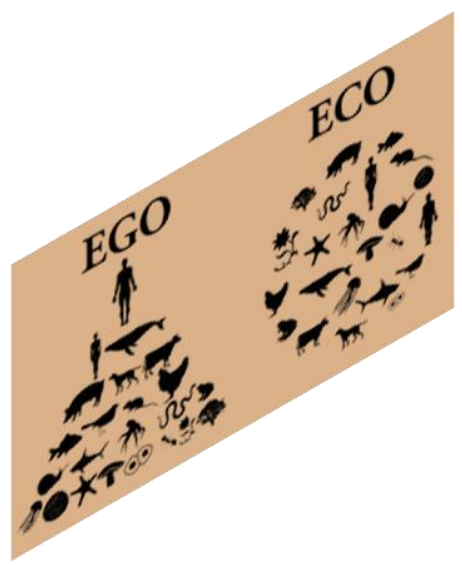

Gambar 1. Grafik antroposentris (ego) dan ekosentris (eco)

\section{Aliran Pemikiran dalam Makro Kosmos}

Masyarakat Indonesia sudah memiliki modal yaitu kearifan tradisional atau etika dan moralitas masyarakat Indonesia mempunyai hubungan yang sangat kuat. Kekuatan kearifan atau etika tradisional tersebut bisa menjadi alternatif di tengah kekuatan sains dan teknologi modern yang cenderungan mengabaikan etika dan lingkungan hidup. Masyarakat Indonesia sudah memiliki modal aliran pemikiran yang bijaksana dimana melibatkan alam semesta (makro kosmos) sebagai bagian dari aliran pemikirannya. Hal ini tergerus dengan masuknya aliran pemikiran antroposentris bersama faham barat masa penjajahan. Jika pada antroposentris hanya memperhatikan hubungan antara manusia dengan sains dan teknologi, maka pada ekosentris memperhatikan hubungan antara sains, teknologi, dan lingkungan hidup. Sonny Keraf merumuskan terdapat 4 jenis hubungan antara ketiganya pada aliran pemikiran antroposentris sampai ekosentris, yaitu:

\section{A. Pendekatan mekanistis-reduksionistis}

Beberapa filsuf membentuk cara pandang antroposentris adalah Galileo Galilei, Fancies Bacon, Rene Descartes, dan Isaac 
Newton. Cara pandang sains dan teknologi modern ini pada dasarnya sekular, mekanistis dan reduksionistis. Sains tidak lagi didasarkan pada prinsip-prinsip apriori yang diterima benar dengan sendirinya, tetapi didasarkan pada pengamatan pencaindra dan metode induksi sebagaimana dikembangkan oleh Fracis Bacon.

Cara pandang mekanistis untuk seluruh alam semesta dan manusia. Keseluruhan aspek dilihat secara mekanistis sebagai semacam mesin yang berfungsi secara mekanistis dan bisa dianalisis dan diprediksikan secara terpisah lepas dari keseluruhan yang membentuknya. Cara pandang reduksionistis adalah realitas di alam semesta, termasuk manusia, dilihat secara reduksionistis dari satu aspek semata-mata tanpa meilihat keterkaitan yang lebih komprehensif dan holistik di antara berbagai aspek.

Fritjof Capra dalam Keraf: menganggap paradigma mekanistis Cartesian ini sebagai penyebab utama masyarakat tidak bisa membangun komunitas yang berkelanjutan, komunitas yang ramah lingkungan, tetapi justru terbangun masyarakat industri yang didominasi oleh pandangan mekanistis tentang dunia. Masyarakat seperti ini memperlakukan lingkungan alam seakan terdiri dari bagianbagian yang terpisah dan lebih mengerikan lagi ditujukan untuk dieksploitasi oleh kelompok-kelompok kepentingan yang berbeda. Bahkan menurut Fritjof Capra, cara berpikir yang mekanistis ini telah membuat kita tercerabut dari alam dan dari sesama manusia yang lain. Kita hidup seakan sebagai bagian yang terpisah dari keseluruhan (Sonny Keraf; 333).

Antroposentris terlalu mengagungkan fakta empiris yang bisa ditangkap oleh pancaindra. Segala sesuatu yang tidak terukur atau bernilai kualitatif tidak diperhitungkan secara serius karena yang diutamakan segala sesuatu yang bernilai kuantatif atau yang bisa dikuantifikasikan, sehingga dianilisis dan dimanipulasi. Alam tidak mempunyai nilai pada diri sendiri, kecuali sebagai alat bagi pemenuhan kebutuhan manusia dan sebagai obyek untuk dianalisis, direkayasa, dan dimanipulasi bagi kepentingan pengetahuan manusia. Pemahaman ini memiliki beberapa kelemahan yaitu 1. etika tidak mendapat tempat dalam keseluruhan pengembangan sains dan teknologi modern, yang dipentingkan adalah fakta, 2. pemanfaatan hasil-hasil sains dan sangat mementingkan nilai instrumentalnya pada sains modern. Manfaat ilmu dan teknologi pun direduksi kepada sekadar manfaat ekonomis-material, 3. Diutamakan nilai kuantitatif dan bukan kualitatif dan berupa ilmu-ilmu keras yang menonjolkan dan mampu menyodorkan data dan fakta-fakta kuantitatif empiris, dan pertimbangan mengenai kepentingan lingkungan hidup selalu dikalahkan dengan kepentingan ekonomis, 4. etika tidak mendapat tempat dalam sains, kecenderungan dasar dalam ilmu pengetahuan dan teknologi modern adalah "dapat" berarti "boleh".

B. Pendekatan holistic

Pendekatan holistik dan sistematik hadir karena disadarinya ada kelemahan-kelemahan paradigma mekanistis-reduksionistis. Bila dikaitkan dengan lingkungan hidup, bisa disebut juga sebagai paradigma atau pendekatan ekologis (Keraf;340). Paradigma holistik adalah suatu paradigma ekologis yang memandang keseluruhan kenyataan secara tekait satu sama lain, termasuk antar subyek dan obyek, antar fakta dan nilai.

Cara pandang sistematik adalah cara pandang dalam kerangka relasi, keterkaitan dan konteks. Semua sistem kehidupanorganisme hidup, ekosistem dan sistem sosiallalu dipandang sebagai keseluruhan yang terkait satu sama lain dan tidak bisa direduksi kepada bagian-bagian yang lebih kecil. Menurut Fritjof Capra, cara pandang holistik dan sistematik ini memungkinkan kita menarik beberapa prinsip ekologi yang dapat kita gunakan daam mebangun komunitas manusia yang berkelanjutan. Prinsip-prinsip ekologis ini adalah kesalingtergantungan, proses ekologis bersifat siklis dan bukan linier, kerja sama dan kemitraan. Selain itu 
ada ketika masing-masing keluar dari batas toleransi oleh sistem kehidupan yang ada, maka akan menimbulkan malapetaka bagi keseluruan sistem kehidupan tersebut.

\section{Kontradiksi sains modern}

Otonomi sains tanpa tanggung jawab moral melahirkan sains dan teknologi yang menghancurkan diri sendiri. Otonomi untuk menjamin obyektivitas kebenaran ilmiah dengan memegang teguh kebenaran dan kejujuran. Hal ini sudah menjadi etos para ilmuwan tetapi kebenaran dan kejujuran dapat diabaikan oleh ilmuwan demi uang dan kekuasaan. Sains mengklaim otonomi yang bebas nilai tetapi perkembangan sains modern semakin dikuasai oleh ekonomi dan politik: oleh kepentingan bisnis. Tunduk dan dikuasai oleh kepentingan ekonomi dan politik, ilmuwan yang begitu mengagungkan kemampuan akal budi, kemampuan intelektual, telah direndahkan harkat dan martabatnya sebagai mahkluk ekonomis. Terdapat fenomena menarik yaitu paten atas hak milik intelektual tidak lebih dari demi melindungi kepentingan bisnis. Hasil temuannya yang seharusnya berfungsi sosial dan moral demi meningkatkan harkat dan martabat manusia, demi meningkatkan kecerdasan manusia, dan demi meningkatan peradaban manusia, telah diabaikan dan yang ada adalah dimensi ekonomis oleum untuk diperdagangkan.

\section{Amdal dalam perspektif holistic}

Studi amdal adalah studi ilmiah merupakan seluruh kerangka studi yang dipengaruhi oleh paradigma dan pendekatan ilmiah tertentu, dimana menentukan keefektifan pengendalian kerusakan dan pencemaran lingkungan hidup dari kegiatan dan atau usaha yang dikaji :

1. Aspek yang dikaji harus meliputi semua aspek yang relevan, sehingga menjamin studi amdal benar benar sebuah studi yang lengkap dan komprehensif,
2. Perlu dihindari kecenderungan untuk memusatkan perhatian pada kemampuan teknis dari disiplin sendiri,

3. kecenderungan untuk melihat isu lingkungan hidup sebagai hanya isu teknis perlu ditinggalkan. Isu lingkungan hidup juga isu social, isu moral, dan isu politik.

Hal ini juga terjadi pada kebijakan tentang pilihan teknologi, yang dilibatkan dan diminta pertimbangan adalah ahli-ahli teknologi, sementara tidak pernah ahli ilmuilmu sosial yang menyangkut aspek sosial, budaya, moral psikologis dimintai pertimbangan. Pertimbangan mengenai aspekaspek itu dianggap tidak penting dan tidak relevan, karena paradigma kita sedemikian cartesiannya.

Tidak hanya berhenti dari aliran pemikiran ekosentrisme, terdapat perkembangan lain yaitu fenomenologi lingkungan. Fenomenologi lingkungan adalah usaha untuk melampaui etika lingkungan, karena etika lingkungan masih dalam tema utama tentang aturan, kebiasaan, serta anggapan baik ataupun buruk menyangkut alam (Saras Dewi;148). Fenomenologi menjelaskan secara fundamental hubungan atau relasi antara manusia dengan alam sebagai usaha memecahkan problem disekuilibrium yang terjadi.

\section{Kearifan lokal yang terlupa}

Perencanaan bangunan ramah atau tahan gempa sangat bersinggungan dengan alam. Keberadaan bangunan sangat tergantung dengan keberhasilan struktur dan konstruksi menyokong fungsi didalamnya. Setiap bangunan harus memiliki struktur yang direncanakan, salah satunya dengan mempertimbangkan kekuatan dan kekokohan dan kestabilan dalam memikul beban atau kombinasi beban, termasuk beban gempa. Setiap perencanaan bangunan juga mempertimbangkan pemilihan sistem struktur bangunan yang dipengaruhi oleh: fungsi dan klasifikasi bangunan, intensitas bangunan, penampilan dan/atau arsitektural bangunan, hasil penyelidikan tanah, hasil pengukuran topografi, 
peta zona bencana, ketersediaan material struktur, metoda konstruksi, dan kearifan lokal.

Berdirinya bangunan otomatis bekerja suatu siklus antara aksi (beban yang bekerja) dan reaksi (kinerja sistem struktur). Beban-beban yang bekerja pada sistem struktur bangunan merupakan bagian dari alam semesta. Kehadiran bangunan sebagai benda yang masuk dalam tatanan alam semesta harus diberi perilaku yang sesuai dengan tantanan yang ada di alam semesta tersebut. Kemampuan alam yang diwujudkan dengan tegangan tanah atau kemampuan untuk mendukung beban bangunan dihitung sedemikian rupa sehingga perencana mengetahui kemampuan alam (daya dukung tanah) dalam $\mathrm{kg} / \mathrm{cm} 2$. Perencana tidak memberikan jumlah besar beban yang harus ditahan oleh tanah lebih besar dari kemampuan daya dukungnya. Ini bagian dari suatu rekayasa, sehingga alam masih mampu menerima "sesuatu" berupa beban yang harus dipikulnya.

Kemampuan daya dukung tanah dipaksa untuk memikul total beban sesuai kemampuan daya dukung tanah di lokasi tertentu. Contoh lain alam harus mengikuti kebutuhan manusia, yaitu bangunan yang menggunakan basemen. Segala macam yang berada di dalam bumi digali dan dilubangi bahkan makhluk hidup didalamnya dipindahkan begitu saja tanpa memperhatikan keberlangsungan makhluk hidup tersebut. Kebutuhan ruang sebagai parkir atau ruang lain yang mendatangkan keuntungan. Salah satu cara pandang mekanistis karena seluruh alam semesta, dan juga manusia, terutama dilihat secara mekanistis sebagai semacam mesin yang berfungsi secara mekanis dan bisa dianalisis dan diprediksikan secara terpisah lepas dari keseluruhan yang membentuknya.

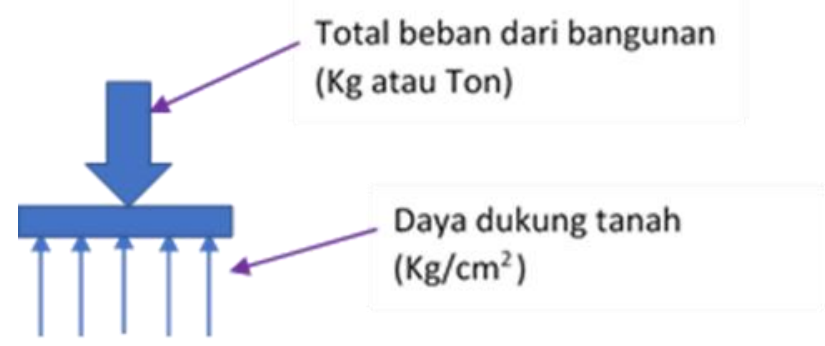

Gambar 2. Ilustrasi beban pada pondasi
Kesadaran akan kekuatan alam dan kebutuhan bangunan yang tahan gempa, juga menjadi pemikiran para manusia, seperti setiap bangunan harus memperhitungkan pendekatan berbasis kinerja (performance based) sesuai dengan fungsi dan klasifikasinya dalam perencanaan terhadap pengaruh berbagai kemungkinan bencana dengan memilih salah satu tingkat kinerja. Manusia membuat beberapa tingkat kinerja operasional yaitu:

1. Tingkat kinerja operasional bangunan gedung (operational approach)

2. Tingkat kinerja pemanfaatan langsung bangunan Gedung (immediate occupancy approach)

3. Tingkat kinerja keselamatan pengguna bangunan gedung (life safety approach)

4. Tingkat kinerja pencegahan terhadap keruntuhan kerusakan bangunan gedung (collapse prevention approach)

Pada tingkat kinerja pemanfaatan langsung bangunan (immediate occupancy approach) ada sikap merespon gempa dengan kondisi bangunan memiliki tingkat kerusakan sangat kecil bahkan dapat diabaikan, sehingga dapat dipastikan bangunan tetap dapat berfungsi dengan baik. Diketahui kekuatan gempa merupakan kekuatan alam yang hanya dapat diperkirakan saja tanpa suatu kemampuan kepastian. Kondisi ini, hak penuh dari alam untuk menentukan kekuatannya. Manusia hanya dapat memprediksi dengan segala macam bentuk perhitungan dan tingkat probabilitas tingkat tinggi, seperti gempa pada zona seismic peta spectral hazard untuk $2 \%$ kemungkinan maksimum selama periode desain 50 tahun. Dimana terdapat peta zonasi gempa yang menjelaskan terjadi kemungkinan 2 persen dengan periode 50 tahun dengan kekuatan tertentu. 


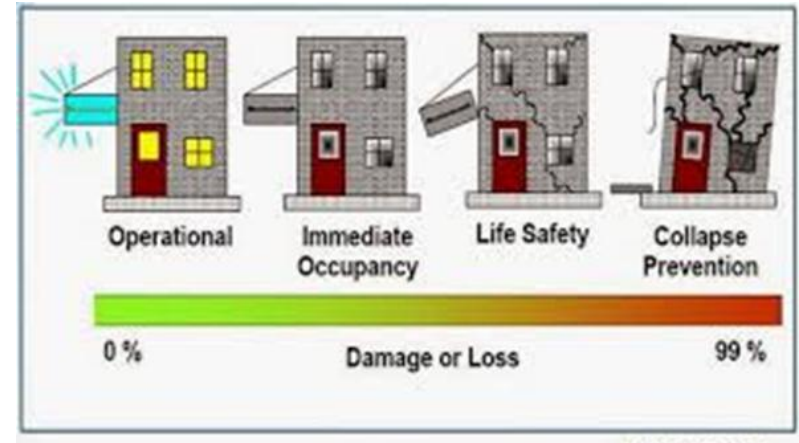

Gambar 3. Kinerja bangunan terhadap gempa

Analisis kehadiran bangunan pada alam semesta (makro kosmos) di atas merupakan lingkup sains modern dan teknologi terkini. Tidak dapat menggunakan pemikiran antroposentris tetapi harus menggunakan pemikiran ekosentris. Alam semesta yang terus berlanjut harus menjadi pemikiran para ilmuwan dalam mengolah sains modern ini. Sains tidak dapat berhenti tetapi sains juga tidak dapat berkembang secara liar tanpa memperhatikan alam semesta. Kearifan lokal masa lalu dalam memandang alam pada arsitektur tradisonal dapat menjadi cermin yang baik bagi para arsitek Indonesia. Para arsitek yang membangun tanpa memperhatikan alam, merupakan suatu kemunduran bagi arsitektur Indonesia. Rumah panggung dengan konsep tanah dapat menyerap air dengan baik. Membuat basemen justru menjadi solusi kebutuhan ruang. Konstruksi bangunan atau rumah tradisional yang menggunakan sistem konstruksi yang dinamis sehingga pada saat gempa, bangunan-bangunan tersebut masih bisa bergerak mengikuti arah gempa dengan kekuatan tertentu.

\section{SIMPULAN}

Sains membiarkan fakta-fakta masuk meskipun fakta itu tidak sesuai dengan dugaan kita sebelumnya. Alasan keberhasilan sains adalah di jantung sains tertanam mekanisme pengoreksi kesalahan. Metode sains, dengan segala ketidaksempurnaannya, dapat digunakan untuk memperbaiki sistem sosial, politik, dan ekonomi, dan itu terus berlaku, apa pun kriteria perbaikan yang diterapkan. Kita menghadapi masalahmasalah melimpah yang tajam dan kompleks. Oleh karena itu kita perlu solusi-solusi yang tajam dan kompleks (Carl Sagan;485).
Para arsitek Indonesia harus bergerak ke arah aliran pemikiran ekosentris dengan nilai kelokalan. Salah satu langkah dengan memperhatikan nilai kelokalan tersebut adalah mempertimbangkan desain yang bersinggungan dengan alam seperti kehadiran basemen dan bangunan tahan gempa dengan level immediate occupancy. Bangunan pada level ini pastinya membutuhkan sistem struktur yang modern, konstruksi yang modern, dan material terkini yang lebih kuat. Ketiga aspek tersebut biasanya memberikan konsekuensi eksploitasi alam, seperti kebutuhan material yang lebih banyak atau lebih kuat mengambil dari sumber daya alam, mempengaruhi keseimbangan makro kosmos. Perlu kesadaran untuk mengolah sains modern yang dapat membantu manusia dan juga tetap menjaga alam semesta. Ini adalah salah satu bentuk sains modern yang dapat membantu kepentingan manusia yang lebih pada nilai sosial, budaya selain nilai ekonomi, teknologi, dan politik.

\section{DAFTAR PUSTAKA}

Azhar, Firdaus. 2012. "Paradigma CartesianNewton Dan Krisis Ekologis" - Tugas Matakuliah Filsafat dan Etika Lingkungan. Depok: Jenjang Magister Program Studi Ilmu Lingkungan Program Pascasarjana.

Capra, Fritjof. 2002. Titik Balik Peradaban. Jogjakarta. Bentang Budaya.

Code Seeker. 2013. "Sains dan Teknologi", https://code6seeker.wordpress.com/2013/03/2 2/sains-dan-teknologi, diakses pada 09 Desember 2018 pukul 20.30

Jimmy, Juwana, 2005. Panduan Sistem Bangunan Tinggi Untuk Arsitek dan Praktisi Bangunan. Jakarta. Erlangga.

Keraf, A. Sonny. 2010. Etika Lingkungan Hidup. Jakarta. Kompas Penerbit Buku.

KMPA Fisip Unsoed. 2012. "Deep Ecology", https://kmpafisipunsoed.wordpress.com/2012 /10/09/deep-ecology, diakses pada 09 Desember 2018 pukul 18.28 
Nasution, M Syukri Albani. 2017. "Filsafat Ilmu”, Depok. Rajawali Pers.

Putri, Luh Gede Saraswati. 2015. Ekofenomedologi: Mengurai Disekuilibrium Relasi Manusia dengan Alam. Tangerang Selatan. CV Marjin Kiri.

Sagan, Carl. 2014. The Demon-Haunted WorldSains Penerang Kegelapan. Jakarta. Kompas Populer Gramedia.

Soeroto, Ir. Myrtha. 2003. Dari Arsitektur Tradisonal Menuju Arsitektur Indonesia. Jakarta. Ghalia Indonesia.

Sugiarto, Bambang, 2008. "Humanisme dan Humaniora Relevansinya Bagi Pendidikan", Bandung Pustaka. Matahari. 